UDC 613:614.2:378.016

https://doi.org/10.26641/2307-0404.2019.1.162168
A.M. Serdyuk,
M.P. Gulich, O.D. Petrenko, L.S. Lyubarskaya, A.V. Koblyanskaya

\title{
THE AWARENESS AND CONSCIOUSNESS OF YOUNG STUDENTS ABOUT THE THREAT OF RISK FACTORS OF DEVELOPMENT OF NON-INFECTIOUS DISEASES - MODERN STATUS OF THE PROBLEM
}

\author{
SI «O.M. Marzieiev Institute for Public Health of the National Academy of Medical Sciences of Ukraine» \\ Popudrenko str., 50, Kyiv, 02094, Ukraine \\ e-mail:gumapa@ukr.net \\ ДУ «Інститут громадського здоров'я імені О.М. Марзєєва НАМН Украӥни» \\ (дир. - академік НАМНУ, д. мед. н., проф. А.М. Сердюк) \\ вул. Попудренка, 50, Київ, 02094, Україна
}

\author{
Цитування: Медичні перспективи. 2019. Т. 24, № 1. С. 4-14 \\ Cited: Medicni perspektivi. 2019;24(1):4-14
}

Key words: sociological research, non-infectious diseases, students, risk factors

Ключові слова: соціологічне дослідження, неінфекційні захворювання, студенти, фактори ризику

Ключевые слова: соичологическое исследование, неинфекичонные заболевания, студенты, факторы риска

\begin{abstract}
The awareness and consciousness of young students about the threat of risk factors of development of non-infectious diseases - modern status of the problem. Serdyuk A.M., Gulich M.P., Petrenko O.D., Lyubarskaya L.S., Koblyanskaya A.V. The purpose of this study was to analyze students' awareness and consciousness about the threat to health of risk factors of chronic non-infectious diseases development, to determine whether they have the skills of a healthy lifestyle and to develop and scientifically substantiate the Algorithm for introducing health-saving educational technologies in the educational process of higher educational institutions of Ukraine. A sociological survey was conducted among students of higher educational institutions of Ukraine regarding the levels of awareness and consciousness about certain factors of non-infectious diseases development. 430 students of the Kiev National University of Trade and Economics and 216 students of Sumy State Pedagogical University were interviewed. A specially designed questionnaire was used. A high level of awareness of students about the main factors in the development of non-infectious diseases - poor nutrition, low physical activity, smoking and alcohol abuse has been established. At the same time, students are not sufficiently conscious about the risk of developing diseases and are unsufficiently motivated to a healthy lifestyle. It is shown a significant difference in indicators of a healthy lifestyle among students of institutions of various profile. The Algorithm for the introduction of health-saving educational technologies into the educational process of higher educational institutions, which is a scientifically substantiated system containing the main tasks, principles and measures aimed at raising the level of awareness and consciousness of young students about the threat to health of risk factors of chronic non-infectious diseases development has been developed. The data obtained are the basis for the improvement of measures for the prevention of non-infectious diseases among students in Ukraine.
\end{abstract}

Реферат. Осведомленность и осознание студенческой молодежью угрозы для здоровья факторов риска развития неинфекционных заболеваний - современное состояние проблемы. Сердюк А.М., Гулич М.П., Петренко Е.Д., Любарская Л.С., Коблянская А.В. Целью данной работьл было: провести анализ осведомленности и осознания студентами угрозы для здоровья факторов риска развития хронических неинфекиионных заболеваний, установить наличие у них навыков здорового образа жизни; разработать и научно обосновать Алгоритм внедрения здоровьесберегающих образовательных технологий в учебный процесс высших учебных заведений Украины. Проведен сочиологический опрос среди студентов высших учебных заведений Украинь касательно уровней осведомленности и осознания отдельных факторов развития неинфекиионных заболеваний. Было опрошено 430 студентов Киевского национального торговоэкономического университета и 216 студентов Сумского государственного педагогического университета. Была использована специально разработанная анкета. Установлен высокий уровень осведомленности студентов касательно основных факторов развития неинфекиионных заболеваний - нерационального питания, низкой физической активности, курения, злоупотребления алкоголем. При этом студенты недостаточно осознают степень риска развития заболеваний и недостаточно мотивированы к ведению здорового образа жизни. Показано существенное различие показателей ведения здорового образа жизни среди студентов разнопрофильных вузов. Разработан Алгоритм внедрения здровьесберегающих образовательных 
технологий в учебный процесс высших учебных заведений, являюшийся научно обоснованной системой, которая содержит основные задачи, принцииы и меры, направленные на повышение уровня осведомленности и осознания студенческой молодежью угрозы для здоровья факторов риска развития хронических неинфекционных заболеваний. Полученные данные являются основанием для совершенствования мероприятий по профилактике неинфекционных заболеваний среди студентов в Украине.

The current public health problem in Ukraine is the rapid and steady growth of chronic non-communicable diseases (NCDs), which negatively affects demographic indicators, ability to work and disability of the population. A particular threat is the fact that the age of non-communicable diseases grew young [18]. According to the World Bank, only $81 \%$ of Ukrainians who reached the age of 15 in 2017 would reach 60 years of age [13]. This indicator clearly shows the threat of NCD to the health and life of the population.

As an integral part of the European process for combating chronic non-communicable diseases, Ukraine has joined the main international initiatives for the preservation of the health of the population $[3,6,15]$. Supporting the WHO policy in Ukraine, based on international documents, there was developed and implemented the "Sustainable Development Strategy "Ukraine - 2020" and the "National Action Plan for Non-Communicable Diseases to achieve the Global Sustainable Development Goal for the period up to 2030" $[11,12,17]$.

Proceeding from the basic provisions of these documents, one of the most important factors in the formation and preservation of human health is the way of life, namely behavioral factors, which play a decisive role in the development of NCDs. This, above all, is irrational nutrition, low physical activity, tobacco smoking, alcohol abuse. According to the WHO strategy, prevention of NCD by changing lifestyles is becoming increasingly important [3. 15]. World practice has proved that, based on the doctrine of "risk factors", there is a real opportunity to prevent NCD not only at the individual level, but also at the population level, especially among young people, due to the formation of their needs in a healthy lifestyle.

Focusing on the prevention of non-communicable diseases for young people is the preservation of the potential of the future health of the nation, an opportunity to significantly influence the formation of a healthy lifestyle, which gives prospects for the implementation of nationwide preventive measures against non-communicable diseases.

Recently, the state, society and scientists have paid greater attention to the problems of the formation and preservation of health of young students. It is a rather specific group of people, which is characterized by increased levels of mental stress and psycho-emotional stress, a sharp change in the lifestyle, a change in social relations, a tendency to risky behavior, etc. $[1,8,20]$. Of particular concern is the increasing incidence of NCDs among students. According to the research conducted, a significant part of the students at the end of professional training suffer from a number of cardiovascular, gastrointestinal diseases, etc. [2, 5, 19].

The best practices based on the latest evidence suggest that the primary focus of the preventive activities of public health facilities on NCDs is to increase awareness about risk factors of the development of NCDs among different social groups. Undoubtedly, raising awareness and awareness among young people about the risk factors of NCD can be a significant component of preventive measures for chronic non-communicable diseases.

Therefore, one of the important tasks of students' training in higher education institutions should be the formation of a healthy lifestyle culture and the mastering of basic knowledge about the risk factors for the development of chronic non-communicable diseases. Unfortunately, in higher educational institutions teaching elements of healthcare-saving disciplines has a non-systematic, situational character $[2,7]$.

However, today, when the system of higher education in Ukraine undergoes significant transformations, there are new opportunities for raising the awareness and understanding by the students of basic principles of a healthy lifestyle and risk factors for the development of NCD [2].

The purpose of this work was to: analyze knowledge and awareness of students about the health risk factors for the development of NCDs, to establish their skills in healthy lifestyle and to develop and scientifically substantiate the Algorithm for the introduction of health-saving educational technologies into the educational process of higher educational institutions of Ukraine

\section{MATERIALS AND METHODS OF RESEARCH}

The research was conducted on the basis of a standardized survey using the questionnaire method. The study used our questionnaire, which takes into account WHO general principles and rules, international requirements for documents that can be used in conducting epidemiological studies $[4,9,10,14]$.

The sociological survey was conducted at two higher educational institutions of Ukraine - the Kyiv National University of Trade and Economics 
(KNUTE) and the Sumy State Pedagogical University (SumSPU). There was studied awareness of future professionals who will implement policy of healthy nutrition in foodservice industry and of future teachers whose professional activities are aimed at advancement of their knowledge and life priorities among future students about healthy lifestyle and factors for NCD development.

430 questionnaires were distributed, received and processed in the KNUTE and 216 questionnaires in the Sumy SPU. All respondents, participating in the survey got questionnaires with the detailed instruction with an emphasis on the necessity for the most accurate filling them in. The survey evaluated, first of all, the degree of prevalence of behavioral risk factors of NCD among young students and their awareness about the factors leading to the development of non-communicable diseases.

The received personal data were processed using traditional statistical methods [16].

\section{RESULTS AND DISCUSSION}

Non-communicable chronic diseases are the main causes of mortality in Ukraine today, but they are not the inevitable result of socio-economic develop- ment. They can be avoided by transforming the social, economic and physical environment that determines behavior related to health. The causes of the NCD are well known and can be effectively addressed, both by individuals and groups of people. To do this, they must be informed and motivated to lead a healthy lifestyle to maintain their health and prevent the development of chronic non-communicable diseases.

According to the comparative analysis of the results of the questionnaire conducted among the students of KNUTE and SumSPU, the level of students' knowledge about the main factors of NCD development was determined (fig. 1). Thus, it is established that the overwhelming majority of respondents are aware of the negative impact of NCD factors on the state of health.

The negative impact of inappropriate nutrition is known to $87.4 \%$ of KNUTE students and to $85.6 \%$ of SumSPU students. Only $12.6 \%$ of the respondents of KNTEU and $14.4 \%$ of those of SumSPU do not know about such a factor of chronic non-communicable diseases development.

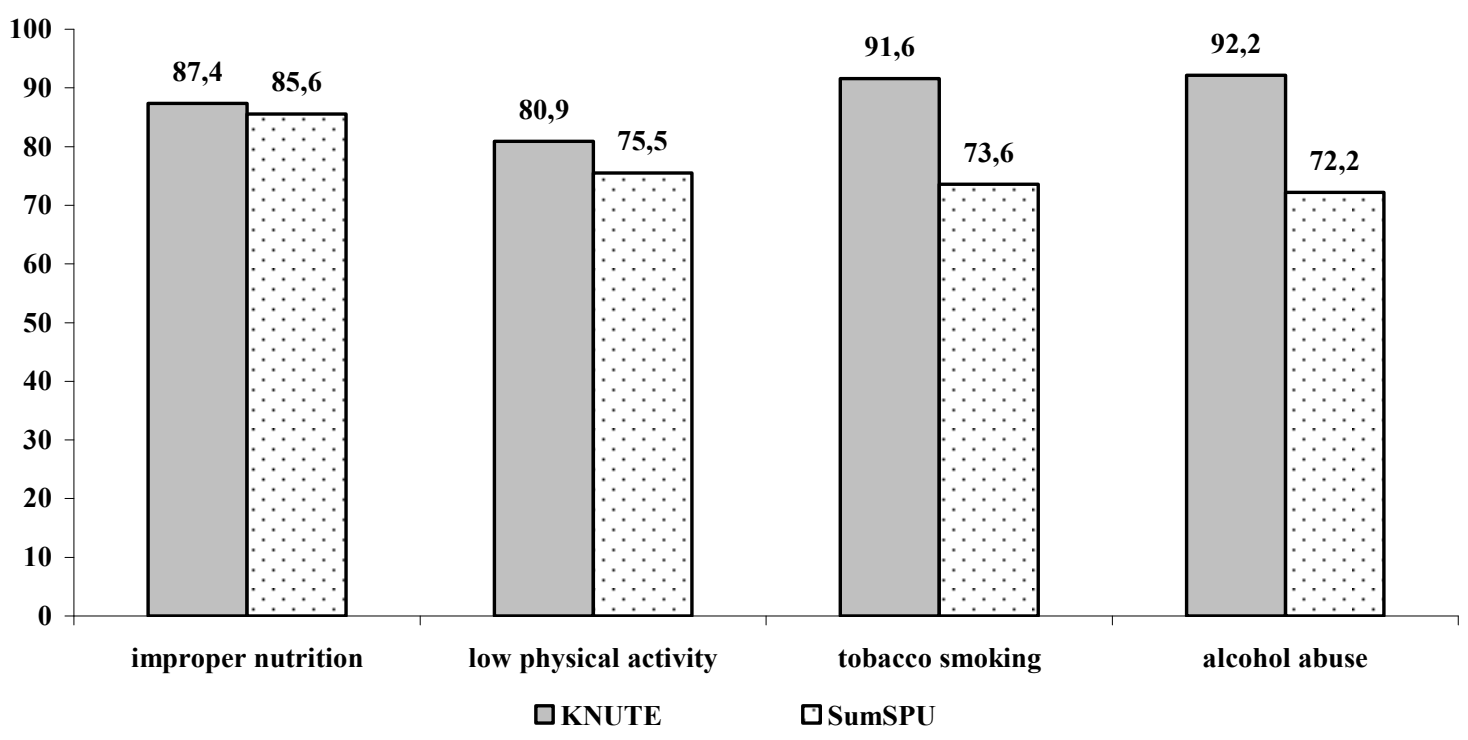

Fig. 1. Segment of students' awareness of the influence of the main factors for NCD development, \%

The number of people informed about the negative impact on the health of low physical activity among the surveyed students of both educational institutions also did not differ significantly. Thus, $80.9 \%$ of students of KNUTE and $75.5 \%$ of those of SumSPU are aware of the impact of this factor.
The indicators of students' awareness about the negative impact of tobacco smoking and alcohol consumption are somewhat different. Almost all of KNUTE students surveyed indicated that they knew about such factors of NCD development as smoking tobacco and alcohol consumption $(91.6 \%$ and $92.2 \%$ 
respectively). The share of SumSPU students, getting the idea about tobacco smoking impact was $73.6 \%$, alcohol consumption $-72.2 \%$. Thus, more than a quarter of the surveyed students of SumPPU are unfamiliar with the negative effects on health of tobacco smoking and alcohol consumption $(26.4 \%$ and $27.8 \%$ respectively). The above results indicate a rather high level of students' awareness of the main factors of NCD development, in particular, inappropriate nutrition, low physical activity, tobacco smoking, alcohol consumption, etc. However, the fact that more than a quarter of SumPPU students are unaware of the risk of smoking smoking and alcohol consumption undoubtedly suggests the need to raise awareness among the contingent, as well as raising the issue of harming impact of tobacco smoking and alcohol consumption into the relevant syllabi of SumSPU.

Comparison of data obtained during the survey has allowed to establish some features of students' nutrition. Thus, about a quarter of respondents studying at KNUTE $(25.8 \%)$, and about a third of students of SumSPU (31.5\%) do not eat fresh fruits and vegetables at all. Sweet carbonated beverages are consumed by $75 \%$ of students of KNUTE and by $82.9 \%$ of SumSPU students. At the same time, a large proportion of those consuming sweet carbonated beverages among students of KNUTE noted that they consume them sometimes, periodically $(41.2 \%)$, while most students of SumSPU consume sweet carbonated drinks constantly (45.4\%) .
Comparing data on salt intake it was found that the relative number of students consuming salt at the level of 5 and 25 grams per day in both educational establishments did not differ significantly and makes up $70.5 \%$ and $24.8 \%$ among students of KNUTE and $73.6 \%$ and $25.0 \%$ among SumSPU students. However, among the students of KNUTE there is a small proportion of people consuming salt at the level of $35 \mathrm{~g} \mathrm{(3.5 \% ),} \mathrm{which} \mathrm{is} \mathrm{absent} \mathrm{among} \mathrm{those} \mathrm{of}$ SumySPU. The proportion of students who consume sugar, adding it to hot drinks, is $77.3 \%$ among the students of SumSPU, which is by $16.4 \%$ higher than the same rate among students of KNUTE (60.9\%).

We also studied the obtained data, taking into account the awareness and gender of the students interviewed.

In the distribution of the data obtained, it was found that, as compared to girls who study at KNUTE, students of SumySPU consume excessive amounts of sugar (table 1). Thus, the consumption of sugar in excessive amounts by girl-students of SumSPU (45.2\%) exceeds the same indicator among girl-students of KNUTE (29.3\%) more than by 1.5 times. In assessing the obtained data, taking into account the awareness of young people, it should be noted that, compared to the students of KNUTE, students of SumSPU consume less amount of carbonated beverages, as well as there is significantly bigger (by 1.4 times) proportion of people who do not consume fresh vegetables and fruits daily (table 2).

\section{Differentiation of girls' answers to the question about improper nutrition as a risk factor for NCD development of different groups of awareness, $\%$}

\begin{tabular}{|c|c|c|c|c|}
\hline \multirow{2}{*}{ Answers under study } & \multicolumn{2}{|c|}{ KNUTE } & \multicolumn{2}{|c|}{ SumSPU } \\
\hline & aware & non-aware & aware & non-aware \\
\hline Consumption of salt per day $25 \mathrm{~g}$ and more & 25,8 & 29,6 & 22,5 & 36,8 \\
\hline Consumption of sweet carbonated beverages & 68 & 74 & $\mathbf{5 7 , 9}$ & 89,5 \\
\hline Add 2 tablespoons of sugar and more to tea and coffee & 29 & 29,6 & 43 & 47,4 \\
\hline Consumption of margarine and spreads & 25,8 & 44,4 & 35,8 & 21,1 \\
\hline Absence in the daily diet of fresh fruits and vegetables & 22,3 & 51,8 & 28,5 & 26,3 \\
\hline
\end{tabular}


Students both of KNUTE and SumSPU also responded as for the level of physical activity, sports and active lifestyle. The share of respondents who gave positive answers to these questions was $45.65 \%$ in SumSPU and $49.5 \%$ in KNUTE, respectively. At the same time, there was no significant difference between the students of SumSPU and KNUTE in the group of informed students engaged in sports.

\section{Differentiation of youths' answers to the question about improper nutrition as a risk factor for NCD development of different groups of awareness, \%}

\begin{tabular}{|c|c|c|c|c|}
\hline \multirow{2}{*}{ Answers under study } & \multicolumn{2}{|c|}{ KNUTE } & \multicolumn{2}{|c|}{ SumSPU } \\
\hline & aware & non-aware & aware & non-aware \\
\hline Consumption of salt per day $25 \mathrm{~g}$ and more & 31,5 & 37,5 & 29,4 & 33,3 \\
\hline Consumption of sweet carbonated beverages & 92 & 93 & 79,4 & 83,3 \\
\hline Add 2 tablespoons of sugar and more to tea and coffee & 41 & 68 & 79,4 & 66,6 \\
\hline Consumption of margarine and spreads & 25,8 & 31 & 41,2 & 33,3 \\
\hline Absence in the daily diet of fresh fruits and vegetables & 25 & 44 & 35,3 & 58,3 \\
\hline
\end{tabular}

The most popular sports among students of KNUTE and SumSPU are work-out in the gym, fitness (among girls) and running. It should be noted that among SumSPU students, especially boys, com- pared with the students of KNUTE, running is much more popular, probably because it is the most appropriate kind of sports (table 3).

Comparative analysis of students who keep fit, by gender, $\%$

\begin{tabular}{l|c|c|c|c}
\hline \multirow{2}{*}{ Kind of sports } & \multicolumn{2}{|c|}{ Students of KNUTE } & \multicolumn{2}{c}{ Students of SumSPU } \\
\cline { 2 - 5 } & youths & girls & youths & girls \\
\hline Gym & 58 & 30 & 39,1 & 50 \\
Fitness & & 30 & 4,3 & 33,5 \\
Running & 25,5 & 29,3 & 50 & 34,7 \\
Swimming & 4,5 & 4 & 13 & 7,1 \\
Other kinds of sports & 12 & 6,7 & 19,6 & 12,4 \\
\hline
\end{tabular}

According to the results of the questionnaire, we received information on the prevalence of such harmful habits as smoking and alcohol consumption. According to the data, smoking is the most common among students of KNUTE (table 4). The largest relative number of smokers consumes from 1 to
10 cigarettes a day. Also, if among the students of KNUTE there were no significant gender differences regarding the use of electronic cigarettes, in SumSPU the share of girls who smoke electronic cigarettes is 3.8 times higher than the corresponding indicator among boys. Also, in SumSPU, a 
significant proportion of students who indicate that they are smoking, but could not determine the frequency (sometimes - very rarely). Among boy- students of SumSPU, this indicator was three times higher, and among girls -5.1 times, compared with students of KNUTE.

Frequency of smoking, by gender, \%

\begin{tabular}{|c|c|c|c|c|}
\hline \multirow{2}{*}{ Frequency of smoking } & \multicolumn{2}{|c|}{ Students of KNUTE } & \multicolumn{2}{|c|}{ Students of SumSPU } \\
\hline & youths & girls & youths & girlsяtb \\
\hline Every day from 1 to 10 cigarettes & 67 & 83 & $\mathbf{5 0}$ & 63,2 \\
\hline Every day more than 10 cigarettes & 11,8 & & 25 & \\
\hline Every day more than 20 cigarettes & & & & 5,3 \\
\hline Electronic cigarettes & 20 & 17 & 12,5 & 47,4 \\
\hline Sometimes smokes & 12,7 & 12,5 & 37,5 & 63,2 \\
\hline
\end{tabular}

Alcohol consumption is an important negative factor affecting the health of young people. Answers of students made it possible to identify the peculiarities of this phenomenon, taking into account gender, awareness, university and course of study. Thus, informed students of both universities less often use alcohol and low alcohol drinks with a certain frequency than non-informed ones. However, the relative number of students who indicated that they consumed alcohol, but could not indicate the frequency (very rarely, on holidays, etc.), in both higher educational establishments is highe among the well-informed students (table 5).

Groups of students who use alcohol and low alcohol drinks, \%

\begin{tabular}{l|c|c|c|c}
\hline \multirow{2}{*}{ Frequency of alcohol consumption } & \multicolumn{2}{|c|}{ Students of KNUTE } & \multicolumn{2}{c}{ Students of SumSPU } \\
\cline { 2 - 5 } & are aware & ignorant & are aware & ignorant \\
\cline { 2 - 5 } $1-2$ times a week & 49 & 55 & 21,8 & 5 \\
$2-3$ times a week & 18 & 18 & 3,2 & 1,3 \\
More than 3 times a week & 12 & 18 & 37,2 & 21,7 \\
\hline
\end{tabular}

Sex differentiation of people who consume alcoholic and low alcohol drinks allowed to detect the following. In both universities under study, the relative share of boys who consume alcohol was higher compared to girls.

However, if this prevalence was insignificant in KNUTE (by 9\%), among the young fellows of SumSPU alcohol consumption was found to be 1.5 times more frequent than that of girls (fig. 2).
The distribution of the relative number of students who consume alcohol, according to the year of study has its peculiarities in every university under the study (fig. 3). Thus, among first and second course students of SumSPU, the number of those consuming alcohol is the smallest, but in senior courses, it rises and at the end of training reaches $66.7 \%$. 
The relative number of KNUTE students who consume alcohol is the highest in the first year $69.0 \%$, which is by 1.8 times higher than that of
SumSPU students. In the last year of study this number is $64 \%$.

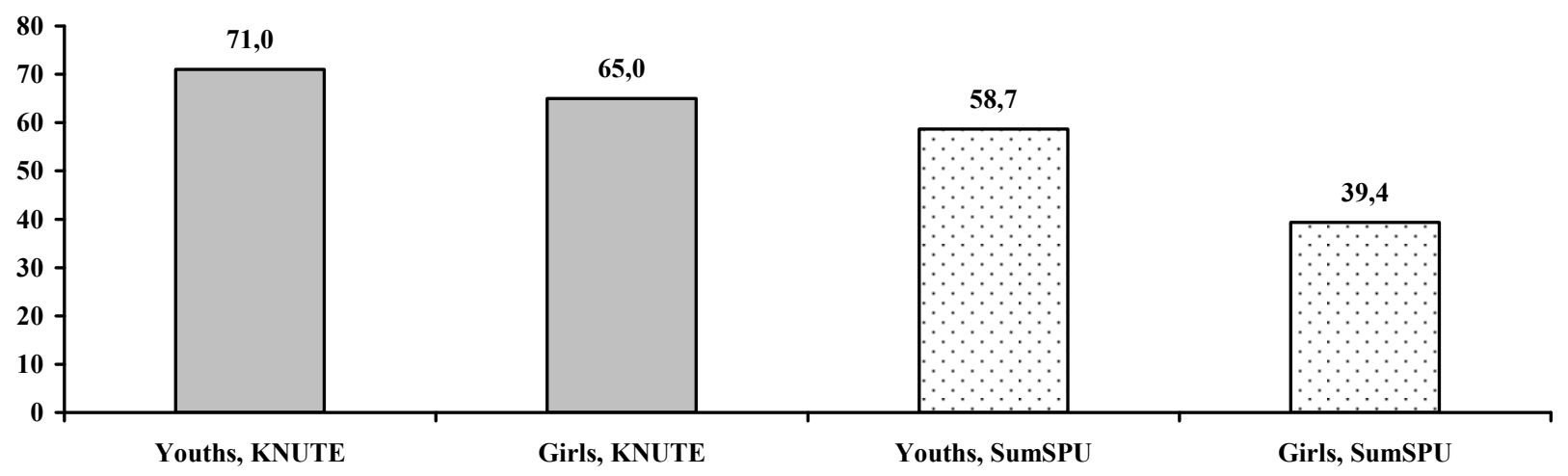

Fig. 2. Comparison of students who drink alcohol and low alcohol drinks by gender, $\%$

Comparing the data on the attitude to drugs and drug abuse, it should be noted that among KNUTE students the experience of consuming such substances is much higher as compared to SumSPU students. Thus, $2.8 \%$ of respondents of SumSPU reported about the experience of drug use, which is 3.7 times lower than the same rate among students of KNUTE $(10.3 \%)$. In contrast to the students of
SumSPU, $2 \%$ of KNUTE students stated about positive attitude towards drug use. The proportion of those who are indifferent to the use of drugs in SumSPU is also significantly lower $(10.6 \%)$ compared to students of KNUTE (18\%). $75 \%$ of of KNUTE students and $89.4 \%$ of SumSPU students have negative attitude to drugs.

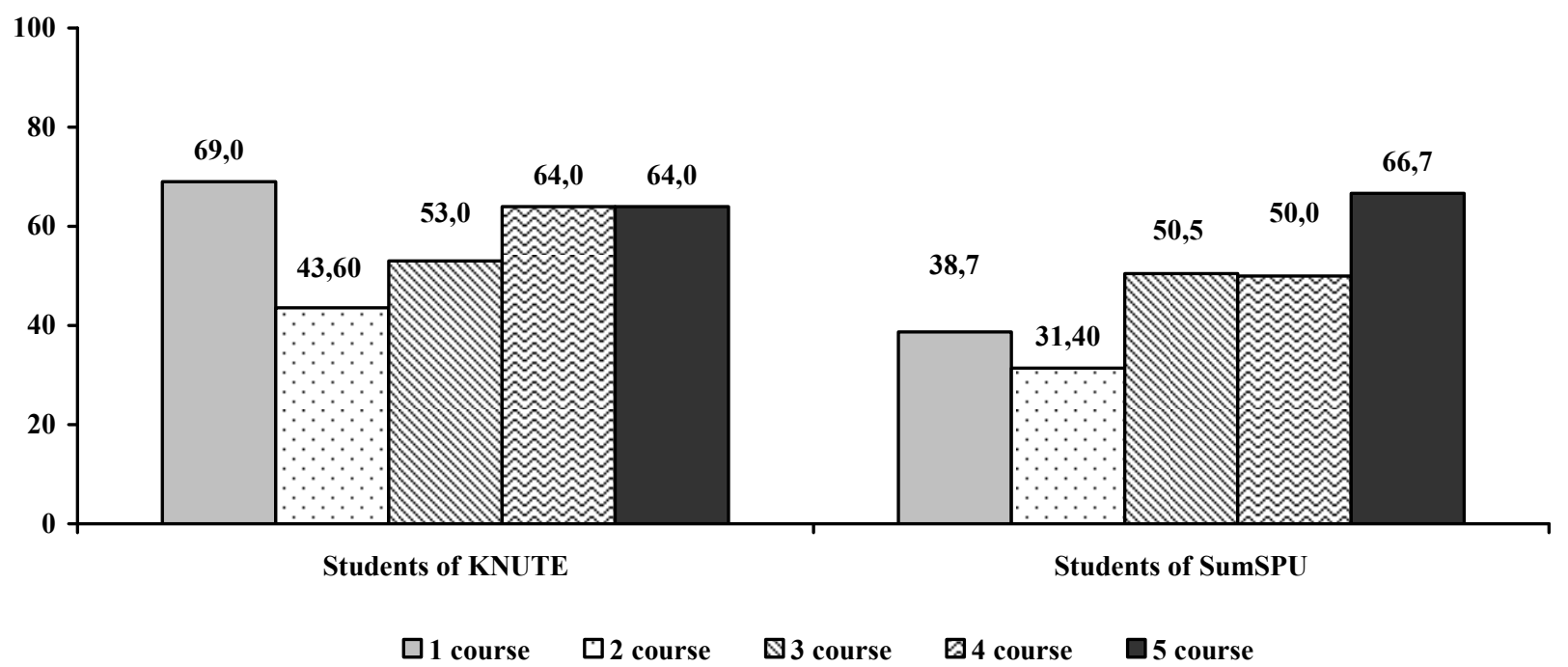

Fig. 3. Distribution of students who use alcoholic and low alcohol drinks, by the year of study, \% 
Studies have shown that despite the students' high awareness, far from all, they are aware and motivated to act according to available knowledge. It has been established that among student youth, in her opinion, there are a number of barriers, stereotypical representations and habits that impede a healthy lifestyle. During the interviews with such factors, students identified the lack of free time $(43.8 \%)$, lack of desire $(30.5 \%)$ and low income $(30.2 \%)$.

We have found that in the educational process of these higher educational institutions there are disciplines that contain elements of knowledge about a healthy lifestyle. It turned out that in KNUTE such disciplines as "Hygiene and sanitation", "Health nutrition" "Technology of special food products" are taught. And in SumSPU there are such departments as "Department of Health, Physical Therapy, Rehabilitation", "Department of Medical and Biological Foundations of Physical Culture". Thus, in both HEE there are disciplines that contain elements of knowledge about a healthy lifestyle.

However, there are differences in the teaching of these disciplines. If in KNUTE more attention is paid to healthy nutrition as a risk factor for the development of diseases, SumSPU focuses more on physical development as a factor of a healthy lifestyle. Therefore, in our opinion, the sociological indicators on the behavioral risk factors concerning smoking and alcohol use obtained in two HEE differ significantly.

Based on own research and literature data, it has been established that there are significant differences in the curriculum of higher educational establishments in the teaching of health-saving disciplines. Often, in the curriculum of training specialists in the fields of knowledge that are not related to the human sciences, in general, such disciplines are absent. In most HEEs which educational profile does not relate to human health, such disciplines are not included in the curriculum, or knowledge on them is presented partly and one-sidedly, in accordance with the requirements of a particular profession. The consequence of this process is an absolute or partial ignorance of a healthy lifestyle and risk of NCD development by a significant number of students.

There is no doubt that one of the important tasks of students' training in higher educational institutions should be the formation of a healthy lifestyle culture in them, and the mastering of basic knowledge about the risk factors for the development of chronic non-communicable diseases.

The solution of the above-mentioned tasks may be the development and implementation of healthsaving educational technologies in the educational process of HEE. The results of the conducted researches and the analysis of the scientific literature on this problem allowed us to develop an algorithm for the implementation of health-saving educational technologies in the educational process of higher educational institutions of Ukraine, which is represented by a number of step-by-step tasks that will ensure the effectiveness of the algorithm and its sensitivity to changes in the relevant sociological indicators (figure 4 )

The Algorithm for the implementation of healthsaving educational technologies in the educational process of higher educational institutions of Ukraine was developed in accordance with and in support of the "National Plan of Measures for Non-Communicable Diseases to Achieve Global Sustainable Development Goals for the Period until 2030" (2018) and "Communication Strategy Prevention of Non-Communicable Diseases in Ukraine until 2025", approved by the experts of the Ministry of Health and the European Bureau of the WHO in Ukraine.

To achieve the main goal of the Agorithm - to raise awareness among young people about the risk factors for NCD development, the formation of healthy lifestyle skills, eight successive tasks have been proposed. At the first stage of the implementation of the algorithm, a sociological study is required to determine the students' awareness about the factors of NCD development, the identification of groups of risk behavior and the analysis of basic educational programs of higher educational institutions that contain components of health-saving knowledge.

On the basis of the obtained data, the development of educational and information technologies on the risk factors of NCD development, taking into account the specificity of both sociological indicators and the availability of basic educational healthcare programs in a particular university.

Taking into account the data obtained, in the development of educational information technologies, it is necessary to take into account the prevalence of stereotypical beliefs about the obstacles to healthy lifestyles and to disclose the main motivational factors of life extension, improvement of the appearance and health, the success of people who lead healthy way of life, its influence on marital status, etc.

Increasing the level of awareness of the risk of NCD development, increasing the motivation of students to lead a healthy lifestyle and reducing risk behaviors is the main expected result of the implementation of the Algorithm. It takes place under the influence of the educational process, organization of extra-curricular classes for students, media support, improving the availability of healthy eating and sports facilities. 


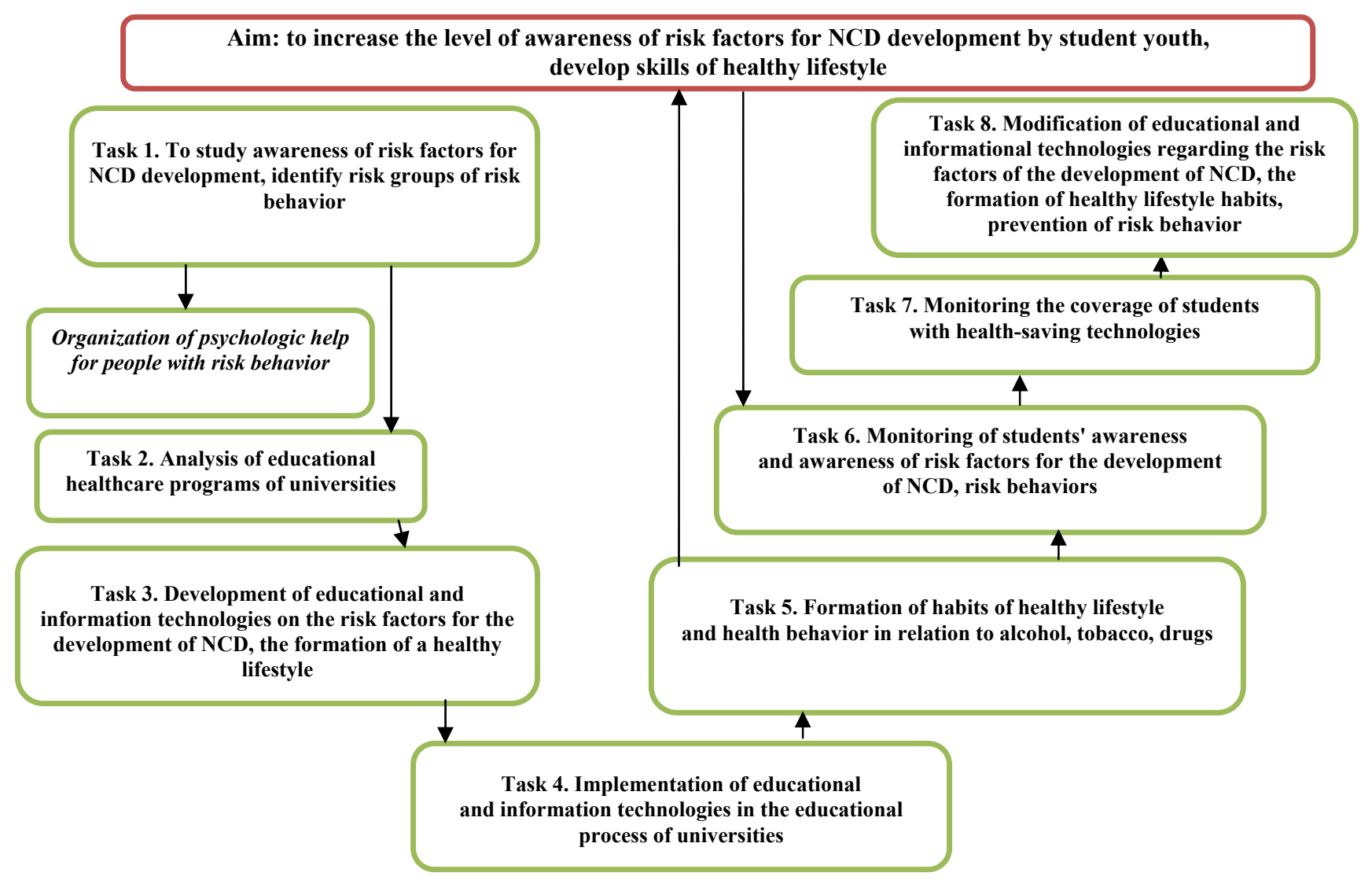

Fig. 4. Algorithm of implementation of health-saving education technologies in training process of higher education establishments of Ukraine

Evaluation of the effectiveness of Algorithm implementation in a comparative analysis of sociological indicators of awareness of NCD development by students at the beginning of Algorithm implementation and at the end of the training course with the use of educational and information technologies. Monitoring of performance indicators of the Algorithm is provided by adaptability of educational and information technologies regarding the risk factors for NCD development, the possibility of promptly making changes to individual curricula and their improvement.

\section{CONCLUSIONS}

1. It was established that the overwhelming majority of the students surveyed both of KNUTE and SumSPU are aware that inappropriate nutrition (87.4\% and $85.6 \%$ respectively), insufficient physical activity ( $80.9 \%$ and $75.5 \%$ respectively), alcohol consumption $(92.2 \%$ and $72.2 \%$ respectively) and tobacco smoking $(91.6 \%$ and $73.6 \%$ respectively) are risk factors for NCD development. However, their awareness does not lead to aware- ness of the threat to health of these factors, which are recognized as leading ones in NCD development.

2. It has been determined that student youth is not aware of the health risks and the increasing risk of NCD developing from abuse of salt and sugar, sweet beverages, margarines and spreads, insufficient daily intake of fruits and vegetables, lack of physical activity, tobacco smoking, alcohol abuse, drug abuse, etc.

3 . The results of the conducted research indicate that there are significant differences depending on the profile of the HEE regarding knowledge and awareness by the students of the factors of NCD development, healthy lifestyle habits, prevalence of risk behavior, etc. Such differences, in our opinion, are due to different approaches and directions of teaching health-preserving disciplines in the system of higher education and indicate the need for further refinement and improvement of information and training programs for young people and students in order to increase their awareness of the danger of the main behavioral risk factors of NCD development in terms of maintaining further health. 
4. The developed Algorithm of introducing health-saving educational technologies into the educational process of universities will significantly increase the awareness of the student youth of the risk of the main behavioral risk factors for the development of NCDs in terms of preserving further health, as well as awareness of the need for a healthy lifestyle.
5. In order to increase the effectiveness of the developed Algorithm and its modification, further research in this direction is needed, which will promote the orientation of the pedagogical process of high school to the formation of healthy lifestyle and health behavior skills of Ukrainian student youth.

\section{REFERENCES}

1. Afanasyeva VA, Oginskaya MK, Ogneva LG. [Modern components of a healthy lifestyle of medical students]. Hist. 2017;19:409. Russian.

2. Garmash OI. [Formation of health and healthy lifestyle among students of higher educational institutions]. Available from: http://intkonf.org/garmash-o-iformuvannya-zdorovya-ta-zdorovogo-sposobu-zhittya-ustudentiv-vischih-navchalnih-zakladiv/. Ukrainian.

3. [The Global Plan of Action for the Prevention and Control of Noncommunicable Diseases for 2013-2020]. VOZ. Zheneva. 2014;114. Russian.

4. [European Health Report 2015. Targets and a broader perspective - new frontiers in working with factual data]. VOZ; 2015. Available from: http://www.euro.who.int/ data/assets/pdf file/0006/2937 39/European-health-report-2015-full-bookru.pdf?ua $=1$. Russian.

5. Dorogajkina EM. [The role of health for students and teachers in a modern university]. Reshetnevskie chteniya. 2016;20:508-11. Russian.

6. [Achievement of nine global NCD targets, shared responsibility: Report on the situation of non-communicable diseases in the world, 2014]. VOZ. 2014;16. Russian.

7. Dudorova LYu. [Pedagogical conditions for the formation of the need for a healthy way of life for future teachers in the process of physical education]. [dissertation]. 2009;24. Ukrainian.

8. Zinov'ev NA, Zinov'ev AA, Kupreev MV, Svyatchenko PB. [Awareness of students of a technical college about the parameters of a healthy lifestyle]. Uchenye zapiski universiteta Lesgafta. 2015;11(129):42-47. Russian.

9. [Qualitative indicators for monitoring the achievement of Health 2020 targets]. WHO. Kopengagen. 2014;50. Russian.

10. [WHO brief questionnaire for assessing the quality of life]. The World Health Organization Quality of Life (WHOQOL). BREF. WHO; 2004. Available from: http://www.who.int/substance abuse/research tools/en/ru ssian whoqol.pdf. Russian.

11. [The National Plan of Measures for Non-Communicable Diseases to Achieve Global Sustainable
Development Goals by 2030. The Order of the Cabinet of Ministers of Ukraine dated July 6, 2018, N 530-p / 2018.]. Available from: http://www.kmu.gov.ua/.../pro_zatverdzhennya-nacionalnogo. Ukrainian.

12. [About the Strategy of Sustainable Development "Ukraine-2020". Approved by Decree of the President dated January 12, 2015, No. 5/2015]. Available from: http://zakon2.rada.gov.ua/laws/show/5/2015. Ukrainian.

13. [Human Capital Development Indicators / World Bank. 2018]. Available from: http: // http://www.vsemirnyjbank.org/ru/publication/human-capital. Russian.

14. [Development of indicators for Health 2020 targets. First Expert Group Meeting (Utrecht, the Netherlands, June 18-19, 2012) / WHO. 2012]. Available from: http://www.euro.who.int/ data/assets/pdf fi le/0016/172510/Developing-indicators-for-the-Health2020-targets-Rus.pdf. Russian.

15. [The resolution adopted by the General Assembly of the United Nations on September 25, 2015. 70/1. Transforming our world: the 2030 Agenda for Sustainable Development (70th session of the United Nations General Assembly): A / 70 / L.1]. Available from: http://www.un.org/ga/search/view doc.asp?symbol=A/R ES/70/1\&Lang=R. Russian.

16. [Statistical methods in biomedical research using Excel]. Kyiv, MORION. 2001;408. Russian.

17. [Goals of sustainable development in Ukraine]. Available from: http:// sdg.org.ua/ua/. Ukrainian.

18. [Annual report on the health status of the population, sanitary and epidemiological situation and the results of the health care system of Ukraine. 2014. Ministry of Health of Ukraine]. MOZ Ukraïni. DU «UISD MOZ Ukraïni». Kyiv. 2015;460. Ukrainian.

19. Evrim Çelebi, Cemal Gündoğdu, Aysel Kızılkaya Determination of Healthy Lifestyle Behaviors of High School Students. Universal Journal of Educational Research. 2017;5(8):1279-287.

20. Yakymenko I, Tsybulin O, Shapovalov Ye. Healthy lifestyle behaviors among university students in Ukraine. Dovkillya ta zdorov’ya. 2017;1:41-45.

\section{СПИСОК ЛІТЕРАТУРИ}

1. Афанасьева В.А., Огинская М. К., Огнева Л. Г. Современные составляющие здорового образа жизни студентов медицинских вузов. Хисm. 2017. Вып. 19. С. 409. 
2. Гармаш О. I. Формування здоров'я та здорового способу життя у студентів вищих навчальних закладів. URL: http://intkonf.org/garmash-o-i-formuvannya-zdorovya-ta-zdorovogo-sposobu-zhittya-u-studentivvischih-navchalnih-zakladiv/

3. Глобальный план действий по профилактике неинфекционных заболеваний и борьбе с ними на 2013-2020 гг. / ВОЗ. Женева, 2014. 114 с.

4. Доклад о состоянии здравоохранения в Европе 2015. Целевые ориентиры и более широкая перспектива - новые рубежи в работе с фактическими данными / BO3. 2015. URL: http://www.euro.who.int/_data/assets/pdf_file/0006 /293739/European-health-report-2015-full-bookru.pdf?ua=1

5. Дорогайкина Е.М. Роль здоровья для студентов и педагогов в современном вузе. Решетневские чтения. 2016. №20. С. 508511.

6. Достижение девяти глобальных целей по НИЗ, общая ответственность: доклад о ситуации в области неинфекционных заболеваний в мире, 2014 / ВОЗ. 2014. 16 c.

7. Дудорова Л. Ю. Педагогічні умови формування потреби в здоровому способі життя майбутніх учителів у процесі фізичного виховання: автореф. дис. ... канд. пед. наук: 13.00.04. Вінниця, 2009. 24 с.

8. Зиновьев Н. А, Зиновьев А. А., Купреев М. В., Святченко П. Б. Информированность студентов технического вуза о параметрах здорового образа жизни. Ученые записки ун-та Лесгафта. 2015. № 11 (129). C. 42-47.

9. Качественные индикаторы для мониторинга достижения целевых ориентиров политики Здоровье2020 / ВОЗ. Копенгаген, 2014. 50 с.

10. Краткий опросник ВОЗ для оценки качества жизни. The World Health Organization Quality of Life (WHOQOL) - BREF / BO3. 2004. URL: http://www.who.int/substance_abuse/research_tools /en/russian_whoqol.pdf)

11. Національний план заходів щодо неінфекційних захворювань для досягнення глобальних цілей сталого розвитку на період до 2030 року: Розпорядження Кабінету Міністрів України від 6.07.2018 р. № 530-p/2018. URL: http://www.kmu.gov.ua/.../pro_zatverdzhennyanacionalnogo

12. Про стратегію сталого розвитку «Україна 2020»: Затверджена Указом Президента від 12.01.2015 p. № 5 / 2015. URL: http://zakon2.rada.gov.ua/laws/show/5/2015

13. Показатели развития человеческого капитала. Всемирный банк. 2018. URL: http://www.vsemirnyjbank.org/ru/publication/human-capital

14. Разработка показателей для целевых ориентиров политики Здоровье-2020. Первое совещание группы экспертов (Утрехт, Нидерланды, 18-19 июня 2012 г.) / BO3. 2012. URL: http://www.euro.who.int/_data/assets/pdf_fi le/0016/172510/Developing-indicators-for-the-Health-2020-targets-Rus.pdf

15. Резолюция, принятая Генеральной Ассамблеей ООН 25.09.2015 г. 70/1. Преобразование нашего мира : Повестка дня в области устойчивого развития на период до 2030 года. 70 сессия Генеральной Ассамблеей Организации Объединенных Наций: A/70/L.1. URL: http://www.un.org/ga/search/view_doc.asp?symbol $=\mathrm{A} / \mathrm{RES} / 70 / 1 \&$ Lang $=\mathrm{R}$

16. Статистические методы в медико-биологических исследованиях с использованием Excel. Киев: МОРИОН, 2001. 408 с.

17. Цілі сталого розвитку в Україні. URL: http:// sdg.org.ua/ua/

18. Щорічна доповідь про стан здоров'я населення, санітарно-епідемічну ситуацію та результати діяльності системи охорони здоров'я України. 2014 рік / МОЗ України; ДУ «УІСД МОЗ України». Київ. 2015. $460 \mathrm{c}$.

19. Evrim Çelebi, Cemal Gündoğdu, Aysel Kızılkaya. Determination of Healthy Lifestyle Behaviors of High School Students. Universal J. Educational Research. 2017. Vol. 5, N 8. P. 1279-1287.

20. Yakymenko I., Tsybulin O., Shapovalov Ye. Healthy lifestyle behaviors among university students in Ukraine. Довкілля та здоров'я. 2017. № 1. С. 41-45.

The article was received 2019.01.30 